Wacana, Vol. 11 No. 1 (April 2009): 159-172

\title{
Between eroticism and social criticism The literariness of Shahnon Ahmad's Terdedah (1965)
}

\author{
MOHD. ZARIAT ABDUL RANI
}

\begin{abstract}
In the history of modern Malay literature, the 1960s are labelled by many literary critics as era picisan (the age of dime fiction) because of the flood of karya picisan (dime fiction) in the local market. Karya picisan here refers to works that clearly manipulate sexual themes, with the intent of conjuring an atmosphere of eroticism to attract readers. Critics generally do not consider these works to be karya sastra (literary works) because they do not fulfil two important criteria that commonly classify the term 'literature', namely bahasa yang indah (aesthetic language) and isi yang berfaedah (beneficial content). In the context of this definition of 'literature', Shahnon Ahmad's 1965 novel Terdedah is considered problematic because of incongruities in the estimation of its 'literariness'. As opposed to critics who initially labelled it karya picisan, the 'literariness' of Terdedah was defended by its own author because it contained elements social criticism. This difference in opinion raises an important point regarding the commonly accepted definitions of 'literature' and 'literariness' in Malay literature: after Shahnon proclaimed his novel's worth based on its social criticism, critical reception towards Terdedah showed an unmistakable shift. With respect to this shift of opinion, this article will perform a critical analysis of the meaning of 'literariness' in relation to Terdedah, and in doing so, clearly determine its status as either a karya picisan or karya sastra, based on the definition of 'literature' practised in Malay literature.

KEYWORDS

Literature, dime fiction, literariness.
\end{abstract}

This discussion focuses on the benchmarks used in Malay literature to gauge the literariness of work. An early observation shows that the issue of 'literariness' (kesastraan) is commonly addressed by two distinct modes of

\footnotetext{
MOHD. ZARIAT ABDUL RANI is currently a senior lecturer at the Department of Malay Studies, Faculty of Modern Languages and Communication, Universiti Putra Malaysia. His area of specialization is modern Malay literature. His research interests include literary theory and criticism, gender and sexuality, and rhetoric in fiction. In 2008, he was awarded the Nippon Foundation Fellowships for 'Asian Public Intellectuals' (API) Fellowships Program to carry out a research on gender and sexuality in Indonesian literature. Under this fellowships program, he was invited as Visiting Research Fellow at the Department of Literature, Faculty of Humanities, University of Indonesia, Jakarta, from 1 July 2008 to 31 March 2009. E-mail: zariat@fbmk.upm.edu.my.
}

(C) 2009 Fakultas Ilmu Pengetahuan Budaya, Universitas Indonesia 
measurement, so as to differentiate karya picisan (dime fiction) from karya sastra (literary work). Firstly, however, it is important to elaborate on the usage and comprehension of these two Malay literary terms: Supardy Muradi (1978:170) defines karya picisan as '[...] the graphic depiction of sexual acts occurring and foregrounded within the story, for the sole purpose of stimulating [readers'] desires and increasing sales' ${ }^{1}$ (my translation). Based on his definition of picisan, Supardy Muradi believes that in Malay literature, the inclination of a given work to deliberately manipulate sexual elements in a way that shirks from a serious and critical discussion of the subject is one of the defining characteristics of karya picisan (dime fiction). The lucidity of sexual themes within a work can be observed in its profusion of erotica, foregrounded by an explicit writing style and vulgar use of language. Such methods are said to be deliberate in their execution, in that they function as bait to lure in the reader.

To get a clearer picture of how picisan (dime) and sastra (literature) can be defined, it is worthwhile to explore the scenario illustrated by Ungku Maimunah Mohd. Tahir (henceforth Ungku Maimunah), a prominent Malay literary scholar, of the Malay literary scene in the 1960s. Ungku Maimunah (2003: 18) considers the period to have been dominated by karya picisan, as she states:

Often refered to as sastera cabul, 'pornographic reading material', it gained both the popularity and easy market very quickly [...] By and large, this genre was dismissed as non-literature and remained outside the literary canon. (Emphasis added).

The excerpt from Ungku Maimunah illustrates key points in the comprehension of the term picisan, first of which is the adherence of these karya picisan (or to use Ungku Maimunah's own translation of sastera cabul or 'pornographic reading material') to commercial demand. But a more salient point in the context of this discussion is that these works are not considered to be sastra - which in itself begs a closer examination of the term sastra as it is perceived and used in Malay literature. The clear implication in Ungku Maimunah's above excerpt is that there are existing criteria within Malay literature to identify karya sastra (literary work), and thus to differentiate these works from karya picisan (dime fiction). Her implication is not at odds with the general view of what characterises the term sastra (literature) in Malay literature, as most scholars list 'aesthetic language' (bahasa yang indah) and 'beneficial content' (isi yang berfaedah) as the two criteria by which sastra can be defined. For instance, A. Bakar Hamid, another renowned Malay literary scholar, also acknowledges the presence of legitimate benchmarks used in Malay literature to gauge the kesastraan ('literariness') of a work. As Bakar Hamid (1976: 8) explains:

[...] gambaran sejelas-jelasnya perlakuan seks yang berlaku dan diungkapkan sejelas mungkin dalam cerita, semata-mata untuk tujuan peransang nafsu dan perniagaan (Supardy Muradi 1978: 170). 
[...] in modern Malay literature there are certain standards of value. Not everything written can be considered literary [...] a work must be written in certain forms and fulfil certain aesthetic criteria; only then can it be considered a literary work, [and] be called literature ${ }^{2}$ (my translation).

In this context, Ungku Maimunah lists the same two criteria that define sastra in Malay literature, namely 'aesthetic language' (bahasa yang indah) and 'beneficial content' (isi yang berfaedah): "In general, sastra is used to connote language that is beautiful and content that is good or beneficial" (2003: 54). Her view is in accordance with the established definitions of sastra; the term is generally held to mean 'bahasa yang indah dan isi yang berfaedah' ('beautiful language and beneficial content'). The Kamus Dewan (2005: 1396) for instance, provides the following definition of sastra:

(i) language that is used in books [kitab] [sacred or authoritative works] (noncolloquial language); [or] (ii) art (writing) in the form of prose or verse that has certain special characteristics, [or] (iii) [in the context of traditional literature] book of ancient knowledge, book which contain prophecies (predictions etcetera) ${ }^{3}$ (my translation).

The Kamus Dewan definition above clearly reinforces the view that sastra is defined by two important criteria: 'aesthetic language' (explained as noncolloquial language) and 'beneficial content' (explained in terms of traditional literature), where sastra is taken to refer to book of knowledge. This is also in keeping with Darus Ahmad's (1965: 9) definition of susastra (sastra): 'Su [The prefix 'su' in 'susastra']; translates as beautiful, good, beneficial [...] sastera: defined as letter or book [...] ke-su-sastera-an: a collection of books that are written eloquently and contain beneficial content ${ }^{\prime 4}$ (my translation). An almost similar understanding of sastra can be found in Abdul Rahman al-Ahmadi's (1966:3) definition: 'A collection of good writing, with beautiful language and beneficial content ${ }^{\prime 5}$ (my translation).

Based on the discussion above, it can be concluded that the term sastra in Malay literature can be used to refer to "works written in aesthetic language,

$2 \quad$ “[...] pada kesusasteraan Melayu moden ada ukuran nilai yang tertentu. Tidak semua yang tertulis itu dianggap sebagai hasil kesusasteraan [...] tetapi sesebuah hasil karya itu mestilah ditulis dalam bentuk-bentuk tertentu, memenuhi syarat-syarat keindahan tertentu baharulah dapat dikatakan hasil karya kesusasteraan, dapat memakai nama kesusasteraan" (Bakar Hamid 1976: 8).

"(i) bahasa yang digunakan dalam kitab-kitab (bukan bahasa basahan); [atau] (ii) hasil seni (karya tulisan) dalam bentuk prosa atau puisi yang mempunyai ciri-ciri keistimewaan yang tertentu, [atau] (iii) [dalam konteks kesusasteraan tradisional] kitab ilmu pengetahuan pustaka, kitab yang mengandungi ramalan (perhitungan dalam lain-lain)" (Kamus Dewan 2005: 1396).

"Su; ertinya indah, baik, lebih berfaedah [...] Sastera: ertinya huruf atau buku [...] Ke-susastera-an: kumpulan buku-buku yang indah bahasa dan baik isinya" (Darus Ahmad 1965: 9).

5 "Himpunan karangan yang baik, indah bahasanya serta isinya bagus" (Abdul Rahman Al-Ahmadi 1966: 3). 
with the purpose of imparting beneficial content" (karya yang ditulis dalam bahasa yang indah, untuk menyampaikan isi yang berfaedah). This would then mean that in the context of the comparison between sastra and picisan, the latter term would refer to works that do not adhere to the two basic criteria that characterise the former.

Utilizing both criteria, many literary critics term the 1960s the 'era picisan' (era of dime works) of Malay literary history (Supardy Muradi 1978: 70; Ungku Maimunah 1998: 58). The term first emerged from the observation that works produced during this era displayed a proclivity towards themes of sexuality. Such themes were usually manifest in stories of young love, life in the city, adultery, celebrity sex scandals, prostitution and nightclub activities. It must be kept in mind that this does not imply that sexual themes cannot be explored in sastra; rather, what remains contentious is the way with which these themes are dealt. In karya picisan, sexual themes are not addressed seriously or critically, but are instead manipulated so as to conjure an atmosphere of eroticism, the natural effect of the graphic description of sexual acts and desires. The means by which this state of eroticism is achieved are the writer's writing style and use of language; and in keeping with the inclination of karya picisan towards inducing eroticism, the writing style and language used by the writer are generally vulgar and explicit. According to Ungku Maimunah, these strategies are deliberately employed to entice readers, evident when Malay literature in the 1960s experienced a boom in popularity, with these works dominating the market. Needless to say, picisan era works are considered by many critics to fall far short of achieving the two fundamental criteria that characterise sastra in Malay literature, that is 'aesthetic language' and 'beneficial content'.

In relation to the Malay literary conventions of the 1960s, the prevalence of karya picisan attracted many new writers to the genre, as well as writers who were already established as prominent figures in Malay literature at the time. Among the luminaries contained in the latter group was Shahnon Ahmad (henceforth Shahnon), who began his literary career in the 1950s with his first novel Rentung, which was generally accepted to possess a degree of literariness, labelled by many critics as sastra. However, it is interesting to note that the works of Shahnon published after the mid-1960s seem to be progressively infused with more and more erotica, an inclination in keeping with the trend of that era. Although Shahnon himself acknowledged this trend, terming the period zaman hawa nafsu ('age of desire'), he never denied his involvement in it, as he states (1993: 454): 'Every now and again I wanted to call this period [the 1960s] 'the sensate age'. I wrote many stories that are a part of this period. A lot of these stories are collected in my anthology Anjinganjing $^{\prime 6}$ (my translation; emphasis added). According to A. Teeuw (a renowned professor of Malay Literature from the University of Leiden, who achieved the height of his fame in the 1960s), Shahnon's dime fiction did not contribute to the canon of Malay literature because it dealt with themes that ' $[\ldots]$ revolved

\footnotetext{
$6 \quad$ "Sekali-sekala mahu saya namakan zaman ini zaman hawa nafsu. Saya banyak juga menulis cerpen yang termasuk zaman hawa nafsu ini. Sebahagian besarnya terkumpul dalam antologi Anjing-anjing" (Shahnon Ahmad 1993: 454).
} 
around sex, prostitution, etcetera ${ }^{7}$ (my translation). However, Teeuw explains that Shahnon's second novel Terdedah (1965) stands apart from his other works because the sex in that novel is complemented by social criticism, thus making it hard to classify it as either picisan or sastra. In Teeuw's comparison of Rentung to Terdedah, he concludes that the former attracted him more because of its realistic depiction of Malay society, as opposed to the latter. Without denying Teeuw's claim that social criticism is indeed included in Terdedah, he makes it clear that the novel's major weakness is its inclination towards the Westernised psychological traits of its characters. These psychological traits clearly refer to the sexual desire which guides the actions of its characters, as Teeuw (1966: 110) himself states in the following excerpt:

[...] to me, as an outsider, a Western reader, [Terdedah] does not capture the attention. Modern readers will finds that this book is unoriginal; only parts of it are Malay [...]; this book contains outdated character psychology, because of its common usage among Western writers, to the extent that it can only be resurrected as the basis of a literature by a writer who is truly talented, or one who can adorn this outdated content with a true essence of Malayness ${ }^{8}$ (my translation).

Even though Teeuw's excerpts above acknowledge the inclusion of social criticism in Terdedah, he nevertheless indirectly labels it as a karya picisan because of its prioritisation of the erotic (an element, as has been shown, commonly associated with the term picisan in Malay literature), thus making it difficult for him to label it as sastra. It is important to note that Teeuw is not alone in the matter, because many critics and readers at the time assumed Terdedah to be picisan, as acknowledged by Ungku Maimunah (1998: 102) in her take on the literary conventions surrounding the novel: '[...] Terdedah came to be regarded by some people as pornographic'.

It is also interesting to note that even though Shahnon himself acknowledged his creation of several lowbrow titles, he excludes Terdedah from the list. Shahnon realized that the novella (at only 116 pages) was already regarded as picisan to large sections of the public; an assumption, according to Shahnon himself, that was caused by several factors: firstly, that the illustration on the front cover of the novel featured a semi-nude woman, seen from the back. Shahnon seemingly blames the publisher, Toko Buku Abbas Bandung, for this, claiming that the idea for the novel's cover was the publisher's own. Moreover, Shahnon claims that he had indeed voiced his displeasure at the illustration on the cover, but based on the literary tastes at the time, the publisher was apparently convinced that it would not cause any 1966: 107).

"[...] yang kesemuanya berpusatkan kepada seks, pelacuran dan lain-lain" (Teeuw

8 "[...] bagi saya sebagai orang luar, sebagai pembaca Barat, [Terdedah] tidak amat menarik perhatian. Bagi pembaca moden buku ini tidak begitu asli, sedikit sahaja yang bersifat Melayu [...]; buku ini mengandung semacam ilmu jiwa yang telah usang, sebab amat banyak dipakai oleh pengarang Barat, sehingga hanya dapat dihidupkan kembali sebagai pokok sastera oleh seorang pengarang yang betul-betul ulung kecekapannya, atau yang sanggup memberi baju baharu yang bersifat Melayu tulen kepada isi yang telah haus itu" (Teeuw 1966: 110). 
controversy (Ungku Maimunah 1998: 101-102). Secondly, sexual connotations could be inferred the novel's title itself; Shahnon explains that when he chose the word 'terdedah' ('exposed' or 'uncovered') as the title, he meant to convey the emptiness of the soul which 'exposed' people to unhealthy elements (maintaining that this was the way the word was used in his hometown). ${ }^{9}$ The title was chosen because Shahnon considered it to be in tune with his initial motive to write the novel: to tell the story of the emptiness of man's soul that gives rise to his feral nature, as captured in the novel's subtitle, 'Kisah kebinatangan manusia dalam satu hari satu malam' (A tale of man's bestiality in one day and one night) (Shahnon 1993: 455).

Given Shahnon's defence of Terdedah, it is clear that he was trying to dispel any association of the novel with the label karya picisan. This is also abundantly clear in Shahnon's aforementioned description of the motive behind the writing of his novel, to depict the emptiness of man's soul and the expression of his bestial nature. However, Shahnon admits that he put aside this motive in favour of social criticism, which in his view, dominates the content of the novel, as he states (1993: 455-456):

I wanted to express a cocktail of the emptiness of man's soul, and the animalistic side of human nature [...] But when I reread this novella, I started to feel as if I had failed. The original motive in my head seemed to have led on to something else; it was slanting more towards social criticism, until many of its parts centred on social criticism $^{10}$ (my translation; emphasis added).

From Shahnon's statement above, it is clear that he at odds with the designation of Terdedah as a karya picisan by critics and readers, preferring rather its designation as sastra, given his claim that the novel is imbued with social criticism. Thus, it can be said that Shahnon's statement not only implies Terdedah's positioning as either picisan or sastra, but more importantly, calls into question the very meaning of the terms sastra (literature) and kesastraan (literariness) in Malay literature, because he is effectively introducing new means of gauging the literariness of a given work, or at least, arguing for a different set of evaluative criteria for his own novel as opposed to other works of Malay literature. It is interesting to note that critical opinion of Terdedah began to change after Shahnon's proclamations: where the novel was initially associated with picisan, several parties began to acknowledge the more serious traits of the novel. This view is most notably contained in works such as Laporan panel anugerah sastera negara 1982, and Yusof Hassan's biography of Shahnon, entitled Sasterawan negara Shahnon Ahmad (1990),

\footnotetext{
$9 \quad$ Shahnon Ahmad was born in Kampung Banggul Derdap, Sik, Kedah, a county in the northern part of Peninsular Malaysia.

10 "Campuran antara kekosongan jiwa dengan sifat kebinatangan manusia inilah yang ingin saya sampaikan [...] Tetapi apabila saya membaca kembali novel kecil ini, saya mulai terasa bahawa saya gagal. Motif asal yang tersemat dalam kepala saya nampaknya terbawa ke soal lain; lebih banyak kepada soal-soal kritik sosial, hinggakan banyak bahagian saya pusatkan pada soal-soal kritik sosial" (Shahnon Ahmad 1993: 455-456).
} 
which will be touched on in greater detail below. Suffice to say at this stage that Shahnon identified social criticism in Terdedah as the determining factor in elevating the novel from picisan to sastra, and that the change in the means by which literariness is measured in the novel allows for the blurring of the line between picisan and sastra.

Faced with the above problematic, this article will analyse Terdedah to identify the elements that actually dominate the content of the novel, whether it is social criticism, or merely erotica. This is important because it will not only determine the novel's status as either picisan or sastra, but will also shed light on a few important understandings of the notions of sastra and kesastraan in Malay literature.

\section{Analysis of SHAHNON AHMAD's TERDEDAH}

As discussed earlier, Terdedah was borne from Shahnon's wish to tell the story of the emptiness of man's soul, and the bestial nature that arises within him as a result of it. This, as stated above, is clearly indicated by the subtitle Kisah kebinatangan manusia dalam satu hari satu malam on the front cover. As generally assumed, and as acknowledged by Shahnon himself, the title and subtitle of the book do indeed lead to its association with matters of sexuality. An initial reading finds that there are grounds for this assumption, given that the protagonist is a young woman named Sharifah Shuhada, who is beautiful, rich, recently widowed by the death of her impotent husband, and who now lives in loneliness. The fusion of the character's back story and her characteristics in itself renders her a suitable 'tool' to be used in conveying sexually-related themes. This is because her designation as a young and pretty widow enables the novel to somewhat legitimise the sexual temptations and conflicts that she faces, due to the common perception of the Malay community towards young widows: of them being more sexually experienced than younger unmarried girls. This is further emphasized by the antecedent of Sharifah's 'unhappy' marital life with her late husband, Syed Ghaffar, who was old and impotent, in addition to her loneliness since his death. All of these circumstances would indicate Sharifah's positioning as a woman who now lives in desperate need to fulfil her sexual needs. Furthermore, this positioning is fully utilized when the novel then vividly describes the sexual fantasies that play about in her mind when she examines her own body in front of the mirror, showers, turns about in bed hugging a bolster, observes the flow of egg white, etcetera. Sharifah's speech is also riddled with vulgarities, and she is brave enough to invite her boyfriends over to spend the night at her house. It is safe to say then that the way in which the emptiness of Sharifah's soul is framed through such an expository strategy easily conjures elements of erotica, that serve to entice the reader. It is also worthwhile recalling that the ubiquitous presence of erotica is one of the important benchmarks in determining the sifat kepicisan (lowbrow nature) of a work in Malay literature.

The emergence of these erotic elements are made even more explicit with the introduction of the two major male characters - Syed Mokhsin, a 
promiscuous bachelor, and Adnan, an adulterous married man. Besides taking an interest in Sharifah, both men are depicted as sexual opportunists, who are aware of the desperation of the young widow, and do not hesitate to work towards fulfilling her desires and their own. After the introduction of these male characters, the story then moves on to the 'bartering' episode between Sharifah and Syed Mokhsin/Adnan, with both men planning to meet the protagonist at her house on that night. From this plan, the story then manipulates fully the element of conflict that plays on the mind of all three characters (Sharifah, Syed Mokhsin, and Adnan), who are all described as trying hard to free themselves of intrusions that can halt their meeting. Syed Mokhsin and Adnan are caught between their own responsibilities and their burning desire to bed Sharifah, while she herself works at persuading them to forego their responsibilities, and come to her house. It must be noted that the novel accentuates these struggles by describing in detail the games playing on their minds, especially the visions of what will transpire on the night of the meeting. Such a storytelling technique is also rife with suspense, for it leads the reader to consider the possibility of sex scenes between Sharifah, Syed Mokhsin and Adnan occurring. As the story develops, the conflicts faced by each character are dispelled by their efforts to bring their plan to fruition: Syed Mokhsin rushes back from his visit to a village with the Menteri Besar and heads straight for Sharifah's house; Adnan cuts short his Parti Bumiputra meeting; and Sharifah herself does not cancel her meeting with either man, in the hope that one of them will show up at her house. Thus, it can be said that all three of the main characters share a similar aim: to quench their burning desires for each other, with nearly the entire narrative space of the novel dominated by the realization of this aim. The characters' torrent of sexual desires also adds fuel to the fire, so to speak, by hinting at more lucid depictions of erotica to come.

Furthermore, the introduction of two pairs of supporting charactersRohana and Fakar, and Tijah and Hamid - makes this hint even stronger. As with the previous character manipulation, these supporting characters are also portrayed as being inclined towards sex. Rohana, for instance, is shown to be sexually deprived because she is often left alone by her husband, Adnan, due to his political commitments; as a result, she engages in an affair with Fakar, Adnan's political secretary. Adnan's absence from home on the night of his meeting with Sharifah thus paves the way for Fakar to fulfil his and Rohana's sexual needs. Similarly, Tijah and Hamid, Sharifah's maid and gardener respectively, make their own plans to be together on the night that their employer is to be visited by either Syed Mokhsin or Adnan. Clearly, the 'struggle' that these supporting characters face for the entire duration of the novel is similar to that of the main characters, that is to act upon their desires and pair up with their respective partners. From this observation it can be gleaned that these characters are adeptly employed to foreground the novel's focus, the issue of human sexual desire. This in itself confirms that Shahnon's motive to write Terdedah, which was convey both the emptiness of man's soul 
and his feral nature, has been accomplished, making his choice of the word 'terdedah' for the title of the novel very accurate indeed.

What also warrants discussion is the morality of the characters, visible in the dynamics of each partnership. It can be said that the characters inhabiting the novel's fictive universe do not hold strongly to their Islamic beliefs; this enables them to entertain desires prohibited by Islam, and subsequently act upon them. It must be noted that each character's readiness to involve themselves in promiscuous relationships reflects their deviation from Islam. Sharifah, for instance, desires Syed Mokhsin and Adnan simultaneously, and contemplates sleeping with Hamid if her wish is unfulfilled. Both Syed Mokhsin and Adnan seem opposed to the restrictions imposed by their religion as well, with Syed Mokhsin courting Sharifah, the widow of his late friend Syed Ghaffar, without any intention of being legally wed to her, and Adnan cheating on his wife, besides being all too ready to put aside his political commitments to sleep with Sharifah. This readiness to commit the sin of adultery is also exhibited by the partners Tijah and Hamid, as well as Rohana and Fakar, with the added detail of the latter couple betraying Adnan's trust, what with Rohana being his wife, and Fakar being his political secretary. It must be explained that the one common denominator that links the relationship dynamic of each couple is their deviation from Islam, or more directly, the betrayal of their spouses to whom they are wed by Islamic law. In other words, what stands out in Terdedah is the bestial nature of the characters, who are portrayed as being wilfully opposed to their religious restrictions. Some of these characters even rationalise their primal instincts, such as when Sharifah points to the weakness of her late husband's sex drive as an excuse to engage in affairs with Adnan and Syed Mokhsin; Adnan rationalizing that Sharifah is more attuned to his current status than his wife Rohana; as well as Rohana herself indulging in sexual relations with Fakar due to feeling abandoned by Adnan. In relation to this issue of Islamic morality, what also cannot be overlooked is the ending of the story, in which most of the relationships remain intact, even if their plans to engage in sexual relations do not materialise. For instance, Sharifah's affair with Syed Mokhsin is kept a secret when Adnan only stumbles upon them together in the living room, and not in the bedroom; Rohana's affair with Fakar is 'saved' by the crying of her baby, when Adnan returns home unannounced; and Tijah's planned rendezvous with Hamid fails to take place. What is apparent from the character's plans of fulfilling each other's sexual needs being kept intact at the end of the story is that it not only negates any Islamic moral punishment meted out to them, but also accentuates their animalistic traits if viewed in relation to the Islamic moral framework, in keeping with the subtitle 'Kisah kebinatangan manusia dalam satu hari satu malam'. At this stage, it is important to note that the focus on the characters' sexual needs and their primal longings is not diverted from in the slightest throughout the novel, as Shahnon (1993: 81) himself acknowledges: 
Both traits [the emptiness of man's soul and his primal nature] greatly influence the characters; to the extent that in the entire twenty four hours [in which the story takes place] everything that they do, experience, see, hear, and think - are all influenced by their spiritual void and their bestial natures ${ }^{11}$ (my translation; emphasis added).

More importantly, the focus of the story fits with the Shahnon's motive behind writing Terdedah, which was, as stated above, to convey the emptiness of man's soul and the animalistic side of his nature. This in itself casts doubt on Shahnon's other proclamation that this motive was sidelined by his emphasis on social criticism.

Both of Shahnon's statements beg further exploration into the social criticism that apparently dominates the narrative of Terdedah. The observation finds that this social element is presented as the conflict between two social classes, an idea which is seen by many critics as being synonymous with 1950s and 1960s Malay literature (Ungku Maimunah 1998: 17-73). The conflict is introduced because the characters in the novel are composed of two different social classes: Sharifah, Syed Mokhsin and Syed Ghaffar belong to the 'Arab/ upper class', while Adnan, Rohana, Fakar, Hamid and Tijah belong to the 'non-Arab/lower class'. Both of these social classes are pitted together with the common goal of meeting that night to fulfil their sexual needs. It is clear from the analysis, however, that the issue of class differences does not divert the focus of the story away from the characters' sexual desperation and lust. This finding is obtained from the fact that "class issues are subordinated" when the novel's entire narrative space is taken into account: after characters from two different social classes are introduced, they then put aside their class differences to fulfil their sexual needs. For instance, Sharifah, the lonely young widow, is depicted at the beginning of the story as someone who is very conscious of her lineage and class (Arab/upper-class); but she then prioritises the fulfilment of her sexual over class concerns, evident in her evaluation of Adnan as a 'candidate' for sexual favours. What Adnan lacks in lineage (non-Arab) is compensated for in Sharifah's mind by his social position as a political figure (considered to be upper class). Although Shahnon's claim that class issues are presented in the novel, his claim is weakened somewhat when Sharifah decides to seek sexual favours from Hamid (non-Arab/lower class) after failing to be with either Syed Mokhsin or Adnan.

With this narrative development, Shahnon's claim that the issue of class and lineage dominate the narrative space of Terdedah is somewhat undone by the characters' decision to put their lust above all else. Thus, it is clear that the issue of class and lineage is brought up and touched upon momentarily, but is then sidelined by the writer in making Sharifah lust after Hamid. The same effect is also apparent in the interest that both Syed Mokhsin and Adnan take in Sharifah, because it is based on her availability rather than class

11 “Kedua-dua sifat ini begitu besar mempengaruhi watak-watak; sehingga selama dua puluh empat jam itu setiap apa yang mereka lakukan, yang mereka tempuh, yang mereka lihat, yang mereka dengar, yang mereka fikir-semuanya didorong oleh kekosongan jiwa dan sifat kebinatangan" (Shahnon Ahmad 1993: 81). 
considerations; furthermore, neither contemplates taking Sharifah as their lawful wife, a situation in which class considerations could have come into play. Similarly, Hamid, Tijah, Fakar and Rohana are all portrayed as being immersed in their efforts to fulfil their sexual desires, without any tangible evidence of class considerations being taken into account. All that emerges from these depictions is that the characters, who inhabit differing social classes, are rendered equal by their shared desire to act upon their sexual desires.

It is crucial to state that the domination of the characters' sexual desires, and the negation of the class conflict issue (what Shahnon terms social criticism), creates an opportunity for the novel to infuse its fictive world with erotic elements. And it is obvious that this opportunity is utilized fully - evident, for instance, when a significant portion of the novel's narrative space is reserved for scenes brimming with erotic nuances, through the explicit detailing of the characters' facial expressions, physical actions and imaginative fantasies. As previously stated, Sharifah's positioning as a tool for conveying sexuality ensures that every object and action associated with her can be interpreted as having erotic connotations. For instance, the gushing of water from the fountain to the pail (Terdedah, 8) implies eroticism when attention shifts immediately to Sharifah's 'senyuman gatal' (lascivious smile) upon hearing this gush of water, because she was in the midst of a sexual fantasy. In similar fashion, erotic nuances are also evident in the protagonist's observation of a cracked egg, as depicted in this excerpt (10): 'The state of the yolk immersed in the flow of the egg white put a smile on her face ${ }^{\prime 2}$ (my translation). The correlation of the image of the egg white with sex is reinforced in turn by the association of Sharifah's 'lascivious smile' with 'rahsia jasmaniah-rohaniah' (physical and spiritual secret), a phrase commonly associated with sex and erotica. ${ }^{13}$ Sharifah's 'lascivious smile' is also employed in a description of spices covering Tijah's hands (69) to create erotic nuances: 'Sharifah smiled when she saw the hands of her cook smeared [with spices], as if those smeared hands reminded her of something she experienced before ${ }^{\prime 14}$ (my translation). Based on these excerpts, it is clear that the novel creates erotic nuances through the association of events to Sharifah's 'lascivious smile,' the outward manifestation of her sexual fantasies. Thus, the analysis this finds that certain images (the gush of water, the flow of egg white and Tijah's hands smeared with spices) are charged with erotic connotations because they are viewed through Sharifah's eyes. Even images that are not directly followed by Sharifah's 'lascivious smile' still connote the same eroticism because they are viewed through her eyes,

$12 \quad$ Keadaan telur merah bergelumang dengan lendir-lendir putih itu menciptakan satu senyuman pula.

13 The word 'rohani' ('spirit') in Malay is defined as batin ('essence') by the Kamus Dewan Edisi Keempat (Kuala Lumpur: Dewan Bahasa dan Pustaka, 2005), 1339. The word 'batin' in its common usage in the Malay community is associated with sex. For instance, the terms tenaga batin ('sexual energy'), masalah batin ('sex-related problem'), and nafkah batin ('the right to sleep with one's wife in exchange for payment of her keep') are all associated with sex.

14 Sharifah tersenyum melihat tangan tukang masaknya yang berlumuran bagaikan tangan berlumuran itu mengingatkan dia kepada sesuatu yang pernah dialaminya. 
such as in this description of Hamid's physicality (107): 'The oily figure was always at her house during the day. She saw Hamid's figure [...] It was the figure of a strong $\operatorname{man}^{\prime 15}$ (my translation). The eroticism in this scene is easily and directly foregrounded because Hamid's figure is described as occupying her thoughts (107), thus reinforcing the association of his physicality to sex: 'She [Sharifah] needed Hamid. She needed him now; at least for now' ${ }^{16}$ It is evident that these erotic nuances are conjured through the manipulation of language and linguistic aspects, which in turn shrouds the narrative space of Terdedah in a sexual atmosphere, as acknowledged by Yahya Ismail (1965: 6)

Shahnon's speciality $[\ldots]$ is his mastery of language $[\ldots]$ which captures the imagination of the reader [...] [he] illustrates enticing scenes and the reader is only asked to imagine the scenes between Shuhada and Adnan, or what they feel for each other ${ }^{17}$ (my translation).

Logically then, for a novel dominated by manifestations of the erotic, a trait usually associated with picisan, and that has the reputation of being one of Shahnon's creations during the era picisan, it is all too easy to classify Terdedah as karya picisan. The critical reception that Terdedah received, however, shows quite the opposite: several critiques and commentaries (especially after Shahnon maintained that Terdedah was a work of sastra) are seemingly hesitant to pin the label picisan on the novel. Moreover, Terdedah did not stand in the way of, but rather contributed to Shahnon receiving several literary awards, such as the 'Anugerah Pejuang Sastera' (Champion of Literature Award) in 1976 and 'Anugerah Sastera Negara' (National Literary Award) in 1982. Although the literary value of Terdedah has been questioned scholars such as Teeuw, Shahnon's era picisan works, especially Terdedah, were considered by the Anugerah Sastera Negara 1982 judging panel to contain sufficient critical content to be dubbed sastra. This is clear from the panel report (1982: 4): 'Although Shahnon was carried away by the trend [the prevalent writing style during era picisan] [...] he nevertheless tried to present the elements of irony and cynicism $[\ldots]^{\prime 18}$ (my translation; emphasis added). The use of the word 'tetapi' in the report shows a conscious effort on the part of the judging panel to defend the literariness of Shahnon's era picisan works, including Terdedah. Even if it can be argued that Shahnon was complying to the market demands of the time, the panel report makes it clear that their evaluation was only focused

15 Susuk tubuh yang berminyak yang selalu berada di rumahnya bila siang hari. Dia nampak susuk tubuh Hamid [...] Sesuatu itu berupa susuk tubuh lelaki yang benar-benar tahan lasak. ketika itu.

Dia memerlukan Hamid. Dia memerlukan Hamid ketika itu; sekurang-kurangnya

17 Keistimewaan Shahnon [...] ialah penguasaan bahasa [...] yang dapat menangkap imaginasi pembaca sekalian [...] dilukiskan adegan-adegan yang memberahikan dan pembaca hanya disuruh mengkhayalkan sahaja dalam kepala masing-masing babak-babak atau perasaan yang bergelora di jiwa Shuhada dan Adnan (Yahya Ismail 1965: 6).

${ }_{18}$ "Walaupun Shahnon terbawa-bawa juga arus itu [...] tetapi beliau cuba juga mengemukakan unsur ironi dan sinis [...]" (Laporan panel 1982: 4). 
on critical elements ('unsur ironis dan sinis'), which were considered to add a gloss of literariness to Shahnon's works. The elements of sex and vulgarity in those works, despite being acknowledged by the panel ('terbawa-bawa juga arus itu'), were clearly not taken into account, or at least, not considered significant enough to compromise the literariness of the novel. Based on the panel's report, it can be said that the presence of 'critical' elements, can indeed 'save' a work from being lumped together with other karya picisan, and thus labelled as a karya sastra that enhances the reputation of its writer.

The stance taken by the panel is also apparent in Yusof Hassan's take on Terdedah in Sasterawan negara Shahnon Ahmad (1990), a biography specifically written to honour Shahnon's contribution to Malay literature. In the chapter devoted to a discussion of Shahnon's most notable works, Yusof Hassan claims that the element of 'kritik sosial' and 'unsur kemanusiaan' (element of humanity) are actually interwoven in the stories of human sexual desperation in Terdedah. With reference to the storytelling technique, Yusof Hassan considers Terdedah to be a 'pembaharuan' (renewal), because of its account of man's bestial nature in one day and one night, although he does not clarify exactly what is being 'renewed,' or how. His identification of the unsur kemanusiaan in the novel, and the 'renewing' storytelling technique, as well as his entire chapter on Shahnon's works, are sufficient to conclude that Yusof Hassan is hesitant to label Terdedah as a karya picisan, as he states (1990: 34): 'They [the characters in Terdedah] are all chasing after sex but still have traces of humanity within them ${ }^{\prime 19}$ (my translation; emphasis added).

\section{CONCLUDING REMARKS}

Using Shahnon Ahmad's Terdedah as the study text, the analysis makes a few important discoveries on the notion of sastra (literature) and kesastraan (literariness) in Malay literature. These discoveries are generally centred on the two established benchmarks of sastra that are used in the Malay literary tradition to gauge kesastraan, namely 'aesthetic language' (bahasa yang indah) and 'beneficial content' (isi yang berfaedah). To fulfil this criteria, Shahnon includes matters of a serious nature in Terdedah (what he himself terms 'kritik sosial' or social criticism); but in actuality, the novel is predominantly focused on issues of sexuality. However, these issues are handled in a superficial manner, without any serious or critical deliberation. All that emerges from the novel's focus on sexuality is the explicit foregrounding of sexual behaviour and fantasy, which contributes into an infusion of erotica. Nevertheless, Shahnon's inclusion of the 'social criticism' aspect (however nominally), and his claims of its predominance in the novel, clearly influenced Terdedah's critics, in that the perceptions of what constitutes sastra seem to have been altered. In this context, it is safe to say that the issue of 'social class' presented in the novel was part of Shahnon's strategy to avoid Terdedah from being lumped together with other karya picisan, and to present it as a karya sastra (evident in Shahnon being aware

19 "Semuanya memburu seks di samping terdapat unsur-unsur kemanusiaan di dalamnya" (Yusof Hassan 1990: 34). 
of the publisher's wishes and literary tastes during the era picisan). This leads to a re-examination of the notion of sastra that is currently used to determine the kesasteraan of a work, which demands that a work fulfil the criteria of aesthetic language and beneficial content. It is based on these criteria that the Malay literary tradition rejects graphic manifestations of eroticism (generally considered to be neither 'beneficial' nor 'beautiful' because it only serves to excite and entice readers). This is relevant to the case of Terdedah because of its seemingly deliberate utilisation of sexuality to conjure erotic elements, which stimulate the reader. The fact that the novel is generally thought to be a karya sastra, and not a karya picisan, and that it enabled the writer to win prestigious literary awards, point to the reality that the definition of sastra which has been used all this while in the Malay literary tradition, or at least its definition in relation to the literariness of Terdedah, has changed.

\section{REFERENCES}

Abdul Rahman Al-Ahmadi. 1966. Pengantar sastera. Kelantan: Penerbit Kelantan.

Bakar Hamid, A. 1983. Diskusi sastera. Kuala Lumpur: Dewan Bahasa dan Pustaka dan Kementerian Pelajaran Malaysia.

Darus Ahmad. 1965. Persuratan Melayu. Penang: Sinaran Bros. Bhd.

Kamus Dewan. 2005. Kamus Dewan. Edisi keempat. Kuala Lumpur: Dewan Bahasa dan Pustaka. (Edisi pertama 1970).

Laporan panel. 1982. Laporan panel anugerah sastera negara 1982. Kuala Lumpur: Dewan Bahasa dan Pustaka.

Shahnon Ahmad. 1965. Terdedah; Kisah kebinatangan manusia dalam satu hari satu malam. Melaka: Abbas Bandong.

Shahnon Ahmad. 1993. Sastera sebagai seismograf kehidupan. Kuala Lumpur: Dewan Bahasa dan Pustaka.

Supardy Muradi. 1978. Novel-novel erotik Melayu di sekitar tahun-tahun 1960an - 1970an. Bangi: Jabatan Persuratan Melayu, Universiti Kebangsaan Malaysia.

Teeuw, A. 1966. "Kesan seorang luar; Dua novelet karangan Shahnon Ahmad". Dewan bahasa (March): 107.

Ungku Maimunah Mohd. Tahir. 1993. "Perihal kesasteraan novel Salina; Satu undangan untuk merenung kembali tradisi kritikan kita?", SARI 11: $47-61$.

Ungku Maimunah Mohd. Tahir. 1998. Antara kampung dan kota; Rural bias in the novels of Shahnon Ahmad. Bangi: Universiti Kebangsaan Malaysia Press.

Ungku Maimunah Mohd. Tahir. 2003. Readings in modern Malay literature. Kuala Lumpur: Dewan Bahasa dan Pustaka.

Yahya Ismail. 1965. "Terdedah - lahir atau batinnya?", Berita minggu (14 November): 6 .

Yusof Hassan, Mohd. 1990. Sasterawan negara Shahnon Ahmad. Kuala Lumpur: Dewan Bahasa dan Pustaka. 